\begin{tabular}{|ll|}
\hline Received & $: 15$ Maret 2020 \\
Revised & $: 2$ April 2020 \\
Accepted & $: 20$ April 2020 \\
Online & $: 25$ April 2020 \\
Published & $: 30$ April 2020 \\
\hline
\end{tabular}

\title{
Defect Analysis of Carbonsteel Pipe Welding Connections Using Non-Destructive Testing with the Penetrant Test Method
}

\author{
Nur Ichsan Sumardani ${ }^{1, a)}$, Ngainun Ibnu Setiawan ${ }^{2}$, Bebeh Wahid Nuryadin ${ }^{1}$, \\ Dadan Sumardani ${ }^{3}$ \\ ${ }^{1}$ Universitas Negeri Islam Bandung \\ ${ }^{2}$ Balai Besar Logam dan Mesin (BBLM), Bandung \\ ${ }^{3}$ Universitas Negeri Jakarta \\ : ${ }^{a}$ ichsan.sumardani@gmail.com
}

\begin{abstract}
In a welding process carried out on metallic materials is sometimes found defects in the material being tested, it is caused by many factors, such as the lack of good materials used and the lack of perfection of the welding process. At testing, it aims to know the surface defects in carbonsteel pipes to know the defects arising after welding. This test is performed with non-destructive tests (NDT) using Dye Penetrant testing method. This test uses 3 types of liquids, including; Cleaner, Penetrant, and developer. The results of these tests will then be observed whether defects occur after welding and what factors affect it. From the test, results there are known 10 locations defects on the surface of the carbonsteel pipe welding with a type of rounded indication of defects that are then followed up by re-welding on indications of such defects.
\end{abstract}

Keywords: Carbonsteel, surface defect, NDT, Dye Penetrant test.

\begin{abstract}
Abstrak
Pada proses pengelasan yang dilakukan pada material kelogaman, kadang ditemukan kecacatan pada material yang diuji, hal ini disebabkan karena banyak faktor, seperti kurang baiknya bahan yang digunakan dan kurang sempurnanya proses pengelasan. Pengujian ini bertujuan untuk mengetahui cacat permukaan pada pipa Carbonsteel dan mengetahui cacat yang timbul setelah pengelasan. Pengujian ini dilakukan dengan Non Destructive Test (NDT) menggunakan metode Dye Penetrant Testing. Pengujian ini menggunakan 3 jenis cairan, diantaranya; cleaner, penetrant, dan developer. Dari hasil pengujian ini kemudian akan diamati cacatcacat apakah yang terjadi setelah pengelasan dan faktor-faktor apa saja yang mempengaruhinya. Dari hasil pengujian ini diketahui terdapat 10 titik lokasi cacat pada permukaan las pipa carbonsteel dengan jenis cacat rounded Indication yang kemudian ditindaklanjuti dengan mengelas ulang pada indikasi cacat tersebut.
\end{abstract}

Kata-kata kunci: Carbonsteel, Cacat Permukaan, NDT, Dye Penetrant test.

\section{PENDAHULUAN}

Pada proses pengelasan dalam sistem produksi, sering sekali dijumpai kecacatan pada material. Kecacatan tersebut terjadi bukan karena kebetulan, tetapi disebabkan oleh beberapa faktor diantaranya yaitu sumber daya manusia yang kurang ahli, sarana dan prasarana yang kurang mendukung, dan kualitas elektroda yang buruk (Heri, 2011). Untuk mengetahui kecacatan yang terjadi pada material tersebut, maka metode yang sering digunakan adalah NDT (Non Distructive Test). Non Destructive Testing (NDT) dapat diartikan sebagai pemeriksaan yang ditujukan untuk mengidentifikasi adanya 
cacat atau kelemahan pada bahan material tanpa merubah ataupun menghancurkan benda atau spesimen (Moore, 1981). Pada dasarnya, pengujian ini dilakukan agar menjamin bahwa material yang kita gunakan masih aman atau belum melewati damage tolerance (toleransi kerusakan) yang di akibatkan oleh cacat - cacat logam (Wibowo, 2016). NDT terdiri dari beberapa metode yaitu: liquid penetrant inspection, eddy current, radiografi atau X-ray, magnetic particle inspection, dan ultrasonic inspection (Bagus, Rizal, Nisa, \& Muhtadin, 2015).

Dengan menggunakan NDT (Non Distructive Test) banyak manfaat yang didapat, diantaranya adalah biaya dan waktu. Hal itu disebabkan karena pengujian dengan metode NDT tidak merusak material yang diuji. Sehingga perusahaan yang melakukan pengujian tersebut tidak mengeluarkan biaya tambahan untuk mengganti material yang rusak. Selain itu, pengujian tidak memerlukan banyak waktu. Sehingga kegiatan produksi akan semakin optimal (Fadhel Adlansyah, 2013). Metode NDT telah banyak diterapkan dalam penanganan kejadian sehari-hari, seperti menentukan cacat pada pemeriksaan pipa gas (Kim, Yoo, \& Park, 2017). Penelitian ini bertujuan untuk mengetahui adanya cacat pada permukaan lasan (welding), menggunakan pengujian tanpa merusak atau Non Destructive Testing untuk tetap menjaga struktur material tersebut.

\section{METODE}

Pelaksanaan ini dilakukan menggunakan NDT (Non Distructive Test) proses pengujian Dye Penetrant Test (NPT). Penelitian ini dirancang untuk memberikan dasar rasional untuk menilai penerimaan cacat yang terdeteksi oleh NDT dan untuk mengembangkan kriteria hukuman untuk kriteria NDT (Smith, Schneider, Bird, \& Wall, 2018). Sebagai mana yang terdapat pada bagian diagram alir Gambar 1 yang menjelaskan rangkaian proses yang dilakukan dan tahapan-tahapan yang dilakukan. Dimulai dari mengidentifikasi masalah sampai dengan menyimpulkan hasil pengujian.

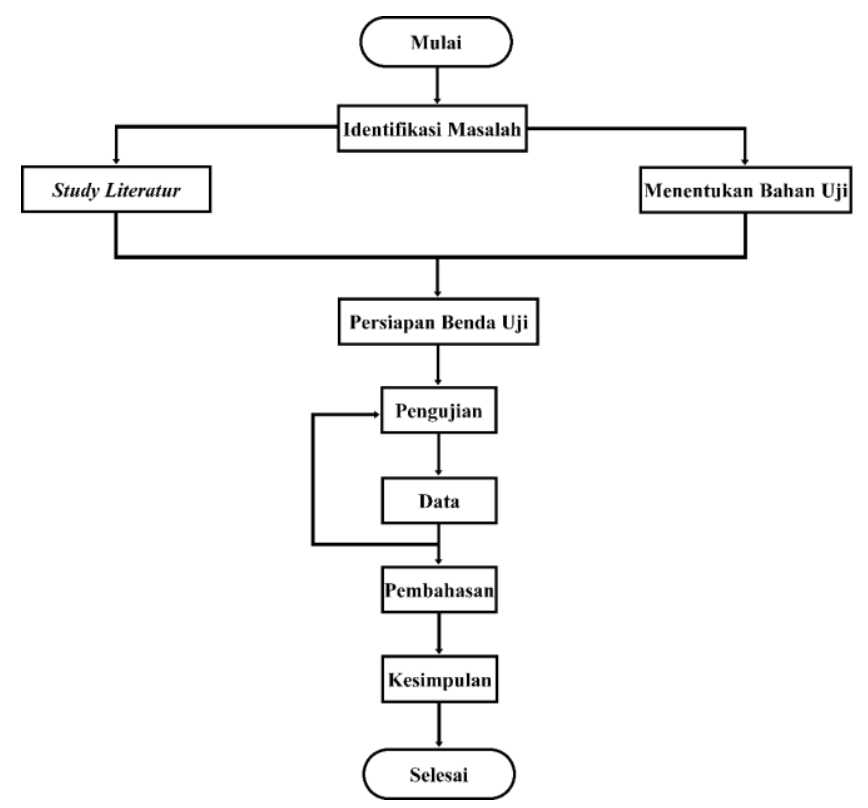

Gambar 1. Flow Chart Proses Pengujian dan Analisis

\section{Identifikasi Masalah}

Identifikasi masalah berdasarkan pengamatan yang telah dilakukan dalam pengujian penetrant inspection menggunakan metode Visible penetrant pada sambungan las pipa logam di Balai Basar Logam dan Mesin sebagaimana berikut :

1. Cahaya yang terang kisaran $20-100 \mathrm{Fc}(100 \mathrm{Fc}=1000 \mathrm{LUX})$. Dalam pengujian ini, cahaya yang di pakai yaitu 1013 LUX atau $101,3 \mathrm{Fc}$.

2. Proses pengujian dilakukan pada sempel uji / Blok AB untuk mengengetahui sensitivitas dari penetrant tersebut. 
3. Proses pembersihan sebelum dan sesudah pengujian sangatlah di perlukan untuk menghindari kotor atau pun korosi.

\section{Alat dan Bahan}

Dalam pengujian ini dibutuhkan alat dan bahan seperti dalam Tabel 1 berikut.

TABEL 1. Alat dan Bahan

\begin{tabular}{|c|c|c|}
\hline No & Bahan & Keterangan \\
\hline \multirow[t]{3}{*}{1} & $\begin{array}{l}\text { SKC - S AEROSOL (Cleaner/Remover) } \\
17 \mathrm{M} 15 \mathrm{~K}\end{array}$ & SPOTBHEBK \\
\hline & & \\
\hline & & Cleaner/Remover \\
\hline \multirow[t]{4}{*}{2} & SKL - SP2 AEROSOL (Red Dye Penetrant) & \\
\hline & 18B09K & SPOTCHECK \\
\hline & & SKL-SP2 \\
\hline & & Penetrant \\
\hline \multirow[t]{4}{*}{3} & SKD - S2 AEROSOL (Developer) & \\
\hline & & SPOTEF \\
\hline & & SKD-S2 \\
\hline & & Developer \\
\hline 4 & $\begin{array}{l}\text { LUX Meter } \\
\text { (Light Master LX-107) }\end{array}$ & \\
\hline 5 & Blok AB & \\
\hline 6 & Bahan/Objek Uji (Pipa Logam) & \\
\hline
\end{tabular}




\section{HASIL DAN PEMBAHASAN}

\section{Hasil Pengujian}

Dari proses pengujian yang telah di lakukan, didapat hasil yang sebelumnya telah dilakukan uji dimensi pada logam dan lasan yang akan di uji terlebih dahulu, berikut adalah dimensi pada Logam dan Las pada Penampang AB dan BA

TABEL 2. Dimensi Logam dan Las Pada Penampang AB dan BA

\begin{tabular}{lll}
\hline $\begin{array}{l}\text { Tebal } \\
(\mathrm{mm})\end{array}$ & $\begin{array}{l}\text { Diameter pipa } \\
(\mathrm{mm})\end{array}$ & $\begin{array}{l}\text { Lebar Las } \\
(\mathrm{mm})\end{array}$ \\
\hline 7,53 & 169,42 & 14 \\
\hline
\end{tabular}

Untuk mempermudah menganalisi Objek/benda Uji digambar kedalam bentuk sketsa Pipa Logam 3D dan Sketsa 2D yang terdapat 2 pandangan atau Penampang AB dan BA untuk mempermudah inspeksi dan tidak tertukar antara cacat 1 dan cacat yang lain (Gambar 3).

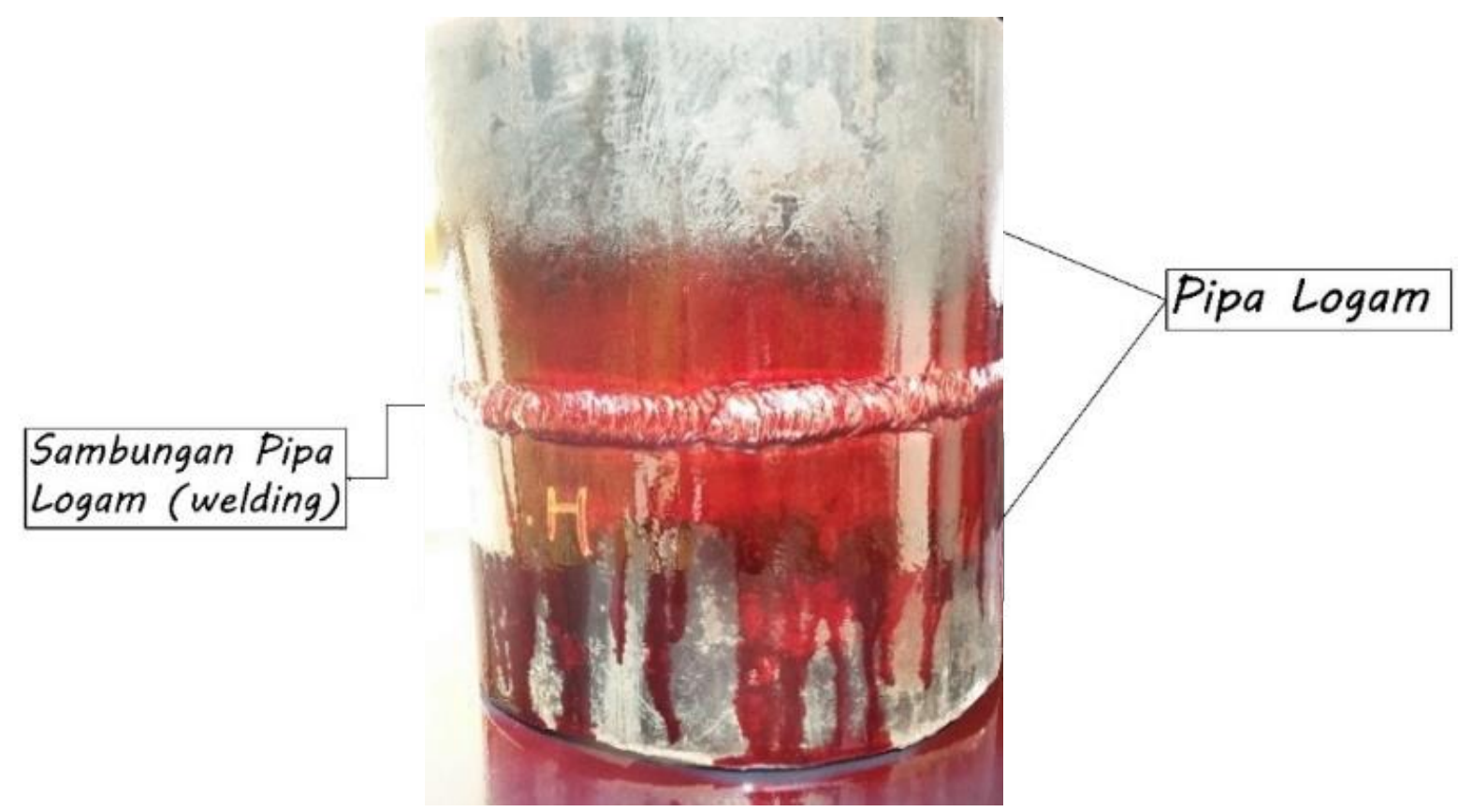

GAMBAR 3. Sketsa Pipa Logam

Setelah melakukan pengujian penetrant tes kemudian digambarkan 2D seperti Gambar 4 sebagai peta lokasi cacat yang tampak dari hasil pengujian, di dapat hasil seperti berikut. 


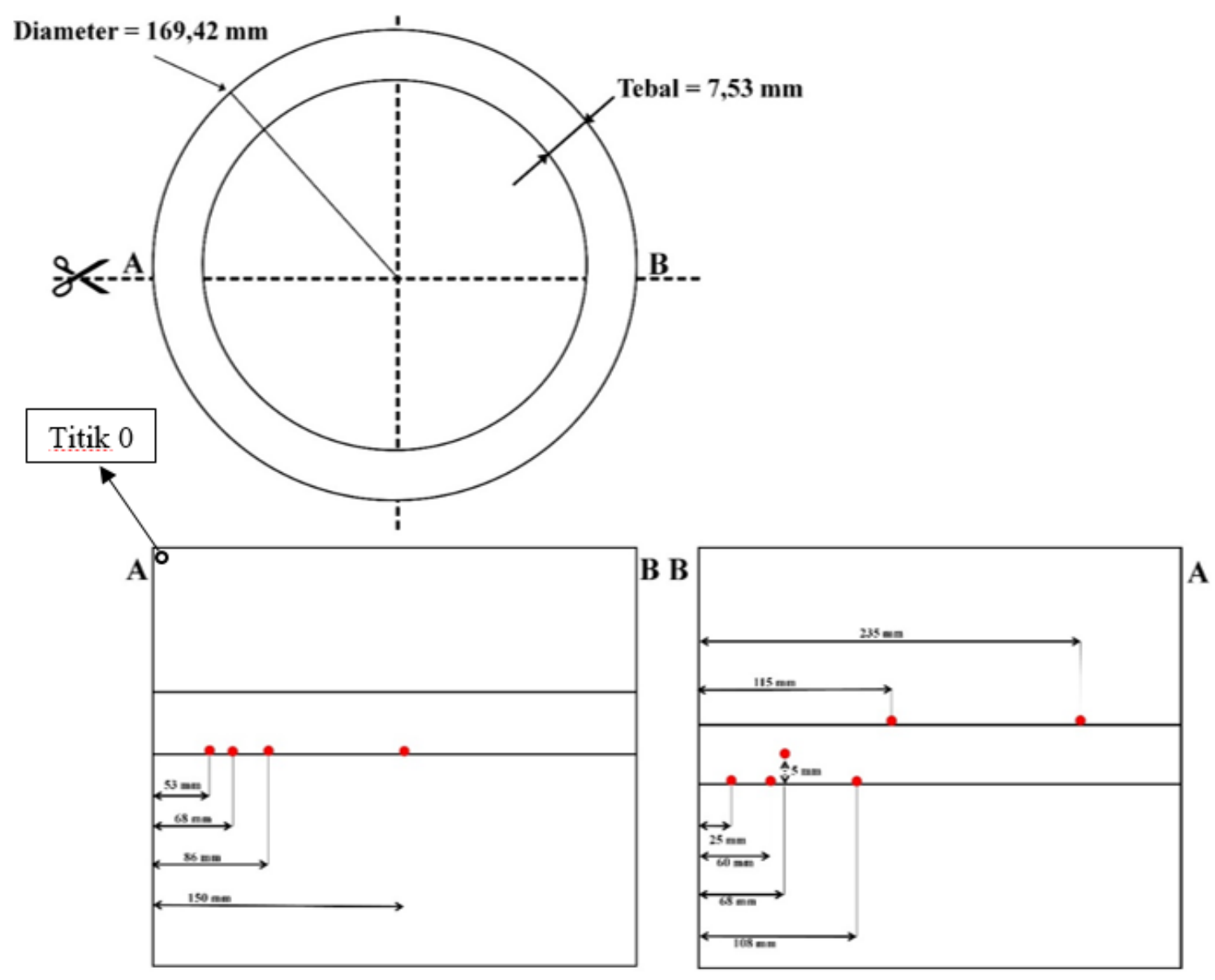

GAMBAR 4. Sketsa 2D cacat permukaan

Dari Gambar 4 dapat diketahui bahwa jarak/lokasi cacat dari titik 0 pada Penampang AB dan BA adalah sebagai mana yang dijelaskan pada Tabel 3 dan 4 berikut.

TABEL 3. Keterangan Cacat yang timbul pada Penampang AB

\begin{tabular}{|c|c|c|c|}
\hline $\begin{array}{l}\text { Cacat } \\
\text { Ke- }\end{array}$ & $\begin{array}{l}\text { Lebar Las } \\
(\mathbf{m m})\end{array}$ & $\begin{array}{l}\text { Lokasi Cacat } \\
\text { Dari titik 0 } \\
(\mathbf{m m})\end{array}$ & Keterangan \\
\hline 1 & 14 & 53 & $\begin{array}{l}\text { Lokasi cacat berada pada jarak } 53 \mathrm{~mm} \text { dari titik } 0 \\
\text { dan berada di titik } 0 \text { paling bawah. }\end{array}$ \\
\hline 2 & 14 & 68 & $\begin{array}{l}\text { Lokasi cacat berada pada jarak } 68 \mathrm{~mm} \text { dari titik } 0 \\
\text { dan berada di titik } 0 \text { paling bawah. }\end{array}$ \\
\hline 3 & 14 & 86 & $\begin{array}{l}\text { Lokasi cacat berada pada jarak } 86 \mathrm{~mm} \text { dari titik } 0 \\
\text { dan berada di titik } 0 \text { paling bawah. }\end{array}$ \\
\hline 4 & 14 & 150 & $\begin{array}{l}\text { Lokasi cacat berada pada jarak } 150 \mathrm{~mm} \text { dari titik } 0 \\
\text { dan berada di titik } 0 \text { paling bawah. }\end{array}$ \\
\hline
\end{tabular}

TABEL 4. Keterangan Cacat yang timbul pada Penampang BA

\begin{tabular}{llll}
\hline $\begin{array}{l}\text { Cacat } \\
\text { Ke- }\end{array}$ & $\begin{array}{l}\text { Lebar Las } \\
(\mathbf{m m})\end{array}$ & $\begin{array}{l}\text { Lokasi Cacat } \\
\text { Dari titik 0 } \\
(\mathbf{m m})\end{array}$ & Keterangan \\
\hline 5 & 14 & 25 & $\begin{array}{l}\text { Lokasi cacat berada pada jarak 25 mm dari titik 0 } \\
\text { dan berada di titik 0 paling bawah. }\end{array}$ \\
6 & 14 & 60 & $\begin{array}{l}\text { Lokasi cacat berada pada jarak 60 mm dari titik 0 } \\
\text { dan berada di titik 0 paling bawah. }\end{array}$ \\
\hline
\end{tabular}




\begin{tabular}{cccl}
\hline 7 & 14 & 68 & $\begin{array}{l}\text { Lokasi cacat berada pada jarak } 68 \mathrm{~mm} \text { dari titik 0 } \\
\text { dan berada di tengah pada jarak } 5 \mathrm{~mm} \text { di titik } 0 \\
\text { paling bawah. }\end{array}$ \\
8 & 14 & 108 & $\begin{array}{l}\text { Lokasi cacat berada pada jarak } 108 \mathrm{~mm} \text { dari titik 0 } \\
\text { dan berada di titik 0 paling bawah. }\end{array}$ \\
9 & 14 & 115 & $\begin{array}{l}\text { Lokasi cacat berada pada jarak } 115 \mathrm{~mm} \text { dari titik 0 } \\
\text { dan berada di titik 0 paling atas. }\end{array}$ \\
10 & 14 & 235 & $\begin{array}{l}\text { Lokasi cacat berada pada jarak } 150 \mathrm{~mm} \text { dari titik 0 } \\
\text { dan berada di titik 0 paling atas. }\end{array}$ \\
\hline
\end{tabular}

Dalam proses hasil pengujian penetrant didapat hasil cacat pada welding dan kemudian digambar pada sketsa 2D untuk mempermudah mengetahui cacat yang timbul, dan kemudian untuk dilakukan tindakan perbaikan cacat tersebut tanpa memperbaiki seluruh welding.

\section{Cacat Lasan Penampang $A B$}

Dari hasil inspeksi ketika melakukan pengujian di dapat cacat pada penampang AB didapat seperti Gambar 5 - Gambar 9 berikut.

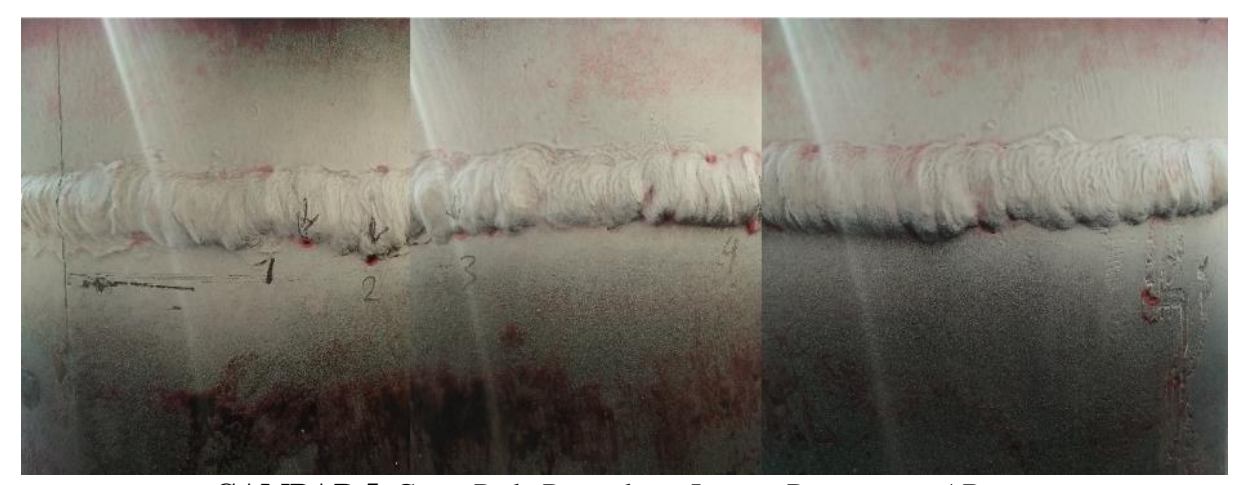

GAMBAR 5. Cacat Pada Permukaan Logam Penampang AB

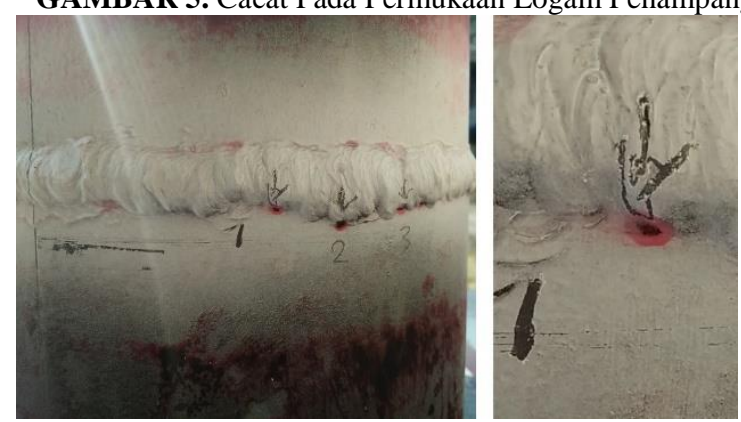

GAMBAR 6. Cacat permukaan ke 1 di Penampang AB
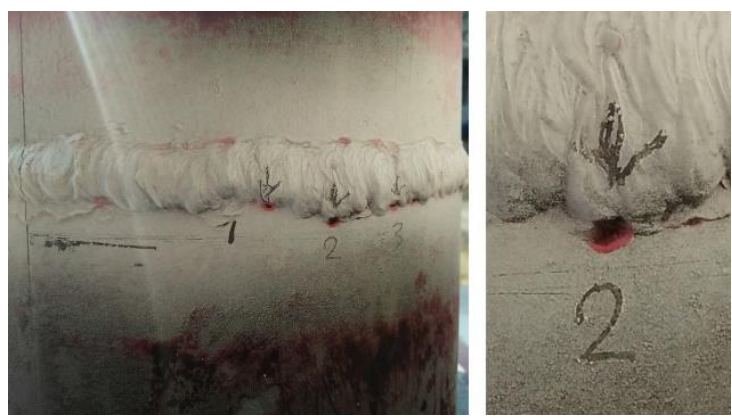

GAMBAR 7. Cacat permukaan ke 2 di Penampang AB 

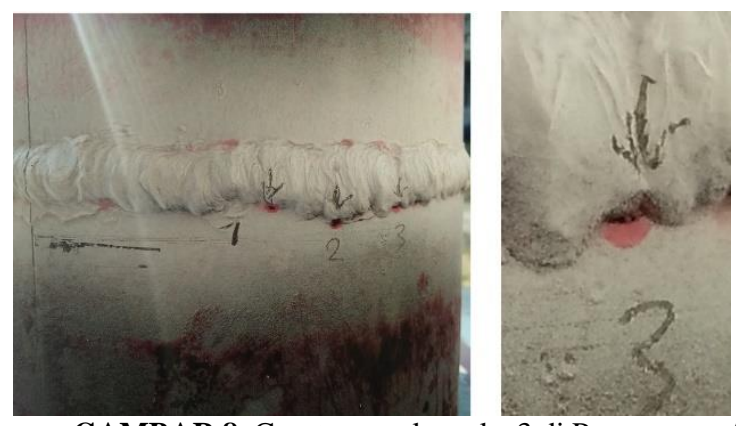

GAMBAR 8. Cacat permukaan ke 3 di Penampang AB

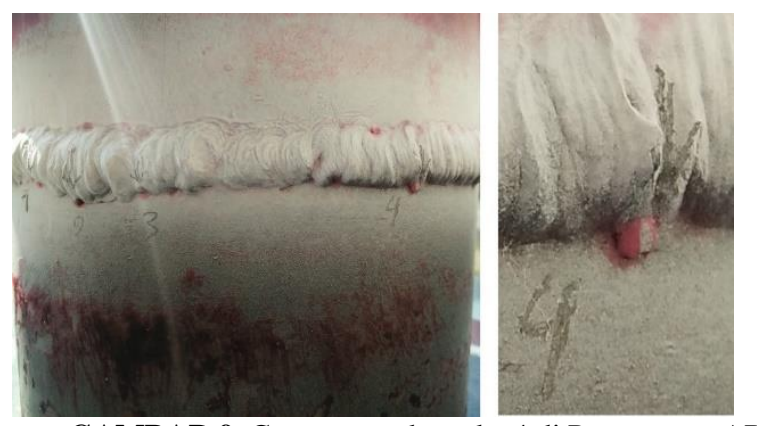

GAMBAR 9. Cacat permukaan ke 4 di Penampang AB

Hasil analisis pada Penampang AB ini dapat di ketahui bahwa jenis cacat yang terjadi termasuk kedalam jenis cacat seperti Tabel 5 berikut.

\begin{tabular}{ll}
\multicolumn{2}{c}{ TABEL 5. Jenis cacat Las yang timbul pada Penampang AB } \\
\hline $\begin{array}{ll}\text { Cacat } \\
\text { Ke- }\end{array}$ & Jenis cacat Las \\
\hline 1 & Round Indication \\
2 & Round Indication \\
3 & Round Indication \\
4 & Round Indication \\
\hline
\end{tabular}

Cacat Lasan Penampang BA

Dari hasil inspeksi ketika melakukan pengujian didapatkan cacat pada penampang BA didapat seperti Gambar 10 berikut. Serta rincian tiap cacat logam digambarkan pada Gambar 11 - Gambar 15.

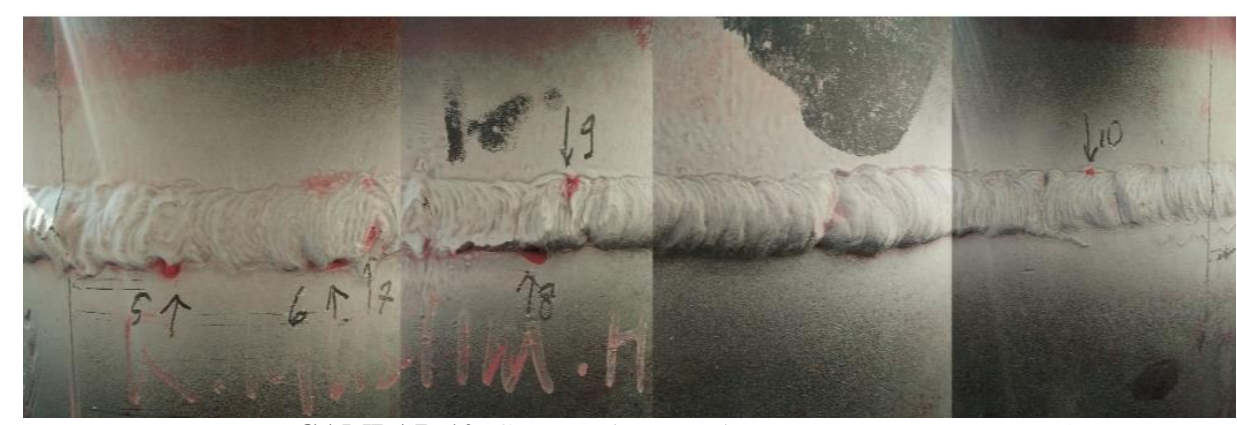

GAMBAR 10. Cacat Pada Permukaan Logam Penampang BA. 

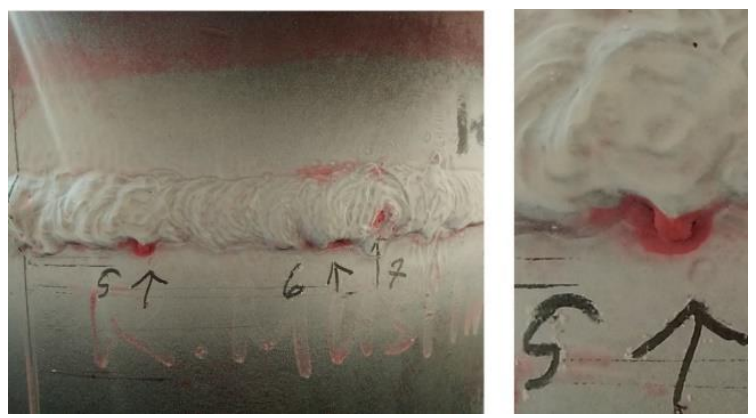

GAMBAR 11. Cacat permukaan ke 5 di Penampang BA
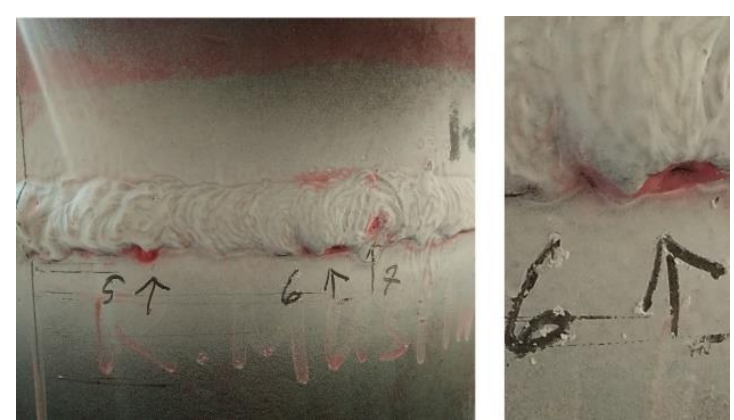

GAMBAR 12. Cacat permukaan ke 6 di Penampang BA
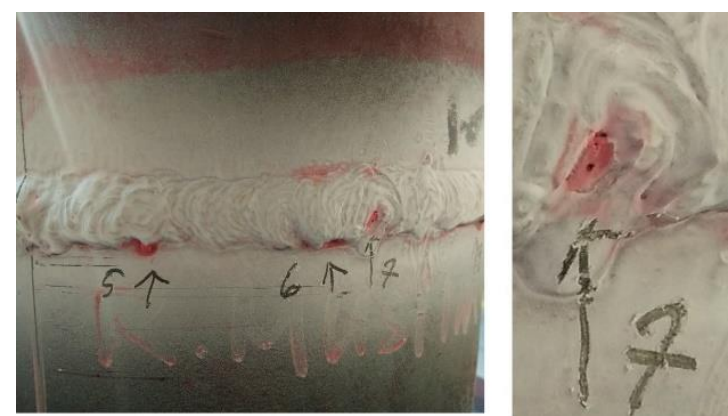

GAMBAR 12. Cacat permukaan ke 7 di Penampang BA
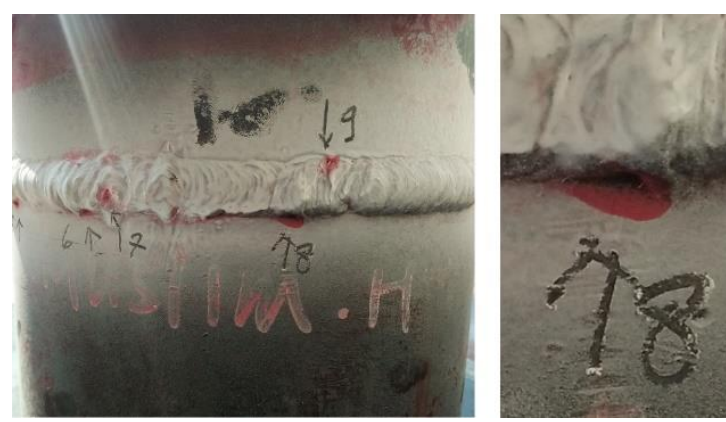

Gambar 13. Cacat permukaan ke 8 di Penampang BA
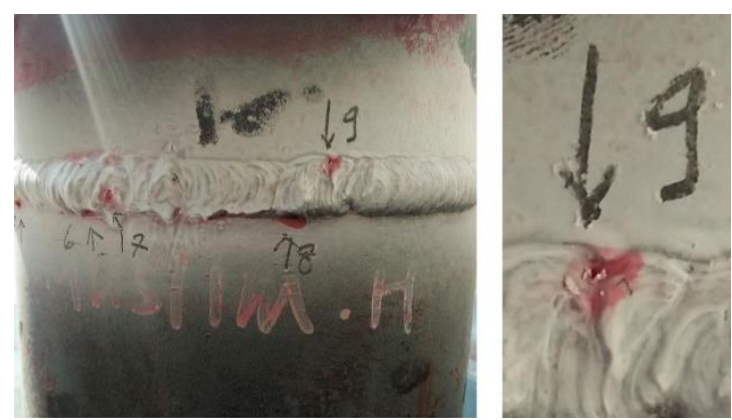

GAMBAR 14. Cacat permukaan ke 9 di Penampang BA 


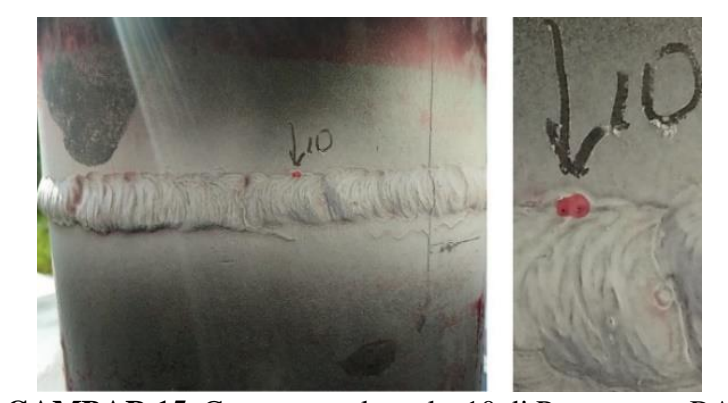

GAMBAR 15. Cacat permukaan ke 10 di Penampang BA

Hasil analisis pada Penampang BA ini dapat diketahui bahwa jenis cacat yang terjadi termasuk kedalam jenis cacat seperti Tabel 6 berikut.

TABEL 6. Jenis cacat Las yang timbul pada Penampang BA

\begin{tabular}{ll}
\hline Cacat Ke- & Jenis cacat Las \\
\hline 5 & Round Indication \\
6 & Round Indication \\
7 & Round Indication \\
8 & Round Indication \\
9 & Round Indication \\
10 & Round Indication \\
\hline
\end{tabular}

\section{Pembahasan Data}

Dari data yang didapat dan diindikasikan bahwa cacat las di semua cacat permukaan dari proses Penetrant Test yang timbul baik itu di Penampang AB maupun di Penampang BA dapat digolongkan kedalam jenis cacat Round Indication (Cacat Bulat). Verifikasi penggolongan cacat dari logam tersebut dilakukan dengan melakukan verifikasi oleh Instruktur NDT Level II.

Cacat jenis ini merupakan cacat las yang diperbolehkan apabila dimensi/ukuran panjang cacat masih berada pada cacat maksimum sesuai kriteria keberterimaan yang digunakan, contoh: lubang lubang mikro (Porosity). Porosity biasanya terjadi karena Elektroda yang digunakan masih lembab atau terkena air, arus pengelasan terlalu rendah, travel Speed terlalu tinggi, adanya zat pengotor pada benda kerja seperti karat minyak, air dan lain-lain (Wibowo, 2016).

Untuk menangani jenis cacat porosity ini biasanya dengan memastikan elektroda yang digunakan sudah dioven (dikeringkan) karena elektroda adalah komponen yang sangat penting dalam menghasilkan kualitas pengelasan yang baik, elektroda yang tidak disimpan dengan baik dapat bereaksi dengan uap air yang berada di udara sehingga menyebabkan bertambahnya kadar hidrogen $\left(\mathrm{H}_{2}\right)$ yang terkandung pada elektroda tersebut. Kadar hidrogen yang berlebihan pada elektroda dapat mengurangi ketangguhan dan menurunkan kekuatan tarik, kemudian ampere yang dipakai disesuaikan dengan prosedur atau rekomendasi dari produsen elektroda yang sesuai berdasarkan ASME IX (Houle \& McGuire, 2002; Wibowo, 2016).

Mempersiapkan pengelasan dengan benar dan memastikan tidak ada pengotor dalam benda kerja. Karena dapat mengakibatkan kurang maksimalnya hasil penegelasan, serta pada material tertentu panas tidak boleh terlalu tinggi karena dapat berakibat pada terjebaknya gas-gas udara di dalam welding yang akan menimbulkan lubang - lubang kecil, juga jangan terlalu rendah karena dapat menimbulkan retak ketika telah dingin atau pun kurang maksimalnya penegelasan (Houle \& McGuire, 2002). Dalam memperbaiki (repair) welding yang telah terindikasi cacat maka dilakukan kembali proses pengelasan yang sebelumnya bahan/objek uji yang telah ditentukan lokasi cacat tersebut tanpa harus melakukan penegelasan ulang (perbaikan Las) pada seluruh lasan.

Dalam proses pengelasan ini werlder dituntut untuk memiliki pengetahuan yang cukup untuk melakukan proses pengelasan sesuai dengan prosedur acuan ASME Section IX (sembilan) yang membahas tentang kualifikasi Juru las (welder). Dalam penentuan cacat logam, NDT dapat pula dilakukan dengan menggunakan Radiography Test untuk mendapatkan data yang lebih spesifik (Senthil, Parameshwaran, Nathan, \& Karthi, 2019). 


\section{KESIMPULAN}

Dari data yang didapatkan, diindikasikan bahwa cacat las di permukaan logam dari proses Penetrant Test yang timbul di Penampang AB maupun di Penampang BA dapat teridentifikasi kedalam jenis cacat Round Indication (Cacat Bulat). Cacat ini timbul karena elektroda yang digunakan masih lembab atau terkena air, arus pengelasan terlalu rendah, travel Speed terlalu tinggi, atau adanya zat pengotor pada benda kerja seperti karat, minyak, dan air.

\section{REFERENSI}

Bagus, M., Rizal, S., Nisa, R., \& Muhtadin. (2015). Praktikum Pengetahuan Bahan Teknik, NDT (Non Destructive Test). Madura: Universitas Trijoyo Madura.

Fadhel Adlansyah. (2013). Non-Destructive Testing (NDT). Retrieved July 8, 2019, from https://blogs.itb.ac.id/fadheladlansyah/2013/10/25/non-destructive-testing-ndt/

Heri, W. (2011). Pengujian LAS - NDT. Yogyakarta: Fakultas Teknik Universitas Negeri Negeri Yogyakarta.

Houle, M. J., \& McGuire, R. D. (2002). CASTI Guidebook to ASME Section IX - Welding Qualifications. Engineering. Edmonton: CASTI Publishing Inc.

Kim, H. M., Yoo, H. R., \& Park, G. S. (2017). Analysis of the Magnetic Characteristics in MFL Type NDT System for Inspecting Gas Pipelines. AETA 2016: Recent Advances in Electrical Engineering and Related Sciences. AETA 2016. Lecture Notes in Electrical Engineering, 415, 319-324.

Moore, H. D. (1981). Materials and Processes for NDT Technology. Materials and Processes for NDT Technology. Columbus: The American Society for Nondestructive Testing.

Senthil, S. M., Parameshwaran, R., Nathan, S. R., \& Karthi, S. (2019). Non-Destructive Testing and Evaluation of Friction Stir Welded AA6063 Circularly Butted Pipes. Russian Journal of Nondestructive Testing, 55(12), 957-966.

Smith, A. T., Schneider, C. R. A., Bird, C. R., \& Wall, M. (2018). Use of Non-destructive Testing for Engineering Critical Assessment: background to the advice given in BS 7910:2013. International Journal of Pressure Vessels and Piping, 1-12.

Wibowo, A. (2016). Macam-Macam Cacat Las. Retrieved October 25, 2020, from http://eprints.uny.ac.id/52508/84/76866500-Macam-Macam-Cacat-Las-Welding-Defects.pdf 